\title{
Progress in N-type Si Solar Cell and Module Technology for High Efficiency and Low Cost
}

\author{
Dengyuan Song ${ }^{1}$, Jingfeng Xiong ${ }^{1}$, Zhiyan $\mathrm{Hu}^{1}$, Gaofei $\mathrm{Li}^{1}$, Hongfang Wang ${ }^{1}$, Haijiao $\mathrm{An}^{1}$, Bo Yu ${ }^{1}$, Brian \\ Grenko $^{1}$, Kevin Borden ${ }^{1}$, Kenneth Sauer ${ }^{1}$, Thomas Roessler ${ }^{2}$, Jianhua Cui ${ }^{1}$, Haitao Wang ${ }^{1}$, Jan Bultman ${ }^{3}$, \\ A.H.G. Vlooswijk ${ }^{4}$ and P.R. Venema ${ }^{4}$ \\ ${ }^{1}$ Yingli Green Energy Holding Co., LTD, 071051 Boading, P.R. China \\ ${ }^{2}$ Yingli Green Energy Europe GmbH, Heimeranstr. 37, 80339 Munich, Germany \\ ${ }^{3}$ ECN Solar Energy, P.O. Box 1, NL-1755 ZG Petten, the Netherlands \\ ${ }^{4}$ Tempress Systems BV, Radeweg 31, 8171 Vaassen, the Netherlands
}

\begin{abstract}
A novel high efficiency solar cell and module technology, named PANDA, using crystalline n-type CZ Si wafers has moved into large-scale production at Yingli. The first commercial sales of the PANDA modules commenced in mid 2010. Up to $600 \mathrm{MW}$ of mass production capacity from crystal-Si growth, wafer slicing, cell processing and module assembly have been implemented by the end of 2011. The PANDA technology was developed specifically for high efficiency and low cost. In contrast to the existing n-type $\mathrm{Si}$ solar cell manufacturing methods in mass production, this new technology is largely compatible with a traditional p-type Si solar cell production line by conventional diffusion, SiNx coating and screen-printing technology. With optimizing all technologies, Yingli's PANDA solar cells on semi-square 6-inch n-type CZ wafers (cell size $239 \mathrm{~cm}^{2}$ ) have been improved to currently have an average efficiency on commercial production lines exceeding $19.0 \%$ and up to $\mathbf{2 0 . 0} \%$ in pilot production. The PANDA modules have been produced and were certified according to UL1703, IEC 61215 and IEC 61730 standards. Nearly two years of full production on scale-up lines show that the PANDA modules have a high efficiency and power density, superior high temperature performance, near zero initial light induced degradation, and excellent efficiency at low irradiance.
\end{abstract}

Index Terms - high efficiency, n-type crystalline Si, solar cell, screen-printing technology.

\section{INTRODUCTION}

Industry analysts agree that the cost of power generation with photovoltaic technology has reached grid parity in many electricity markets, and is poised to continue to decline in the coming years. According to a recent market survey [1], the average global PV module price has reduced from \$4.66/Wp in 2004 to $\$ 1.15 / / \mathrm{Wp}$ in the fourth quarter of 2011, especially down $40 \%$ from the same quarter of 2010. Two leading contributors to this result are the reduction in raw material costs, and continuous improvement in manufacturing, which is largely driven by increasing cell conversion efficiency.

Based on information from GTM Research [2], polysilicon price has collapsed $90 \%$ in the last five years. By the end of
2011, the spot price was down to $\$ 30$ per kilogram from $\$ 80$ per kilogram on March of 2011. Considering that polysilicon supply may not grow faster than demand in the future, polysilicon prices will stabilize to a sustainable level. Therefore, the development of high efficiency and low cost crystalline Si solar cells and modules is the most effective way to lower the cost of solar power.

Currently, p-type Si solar cell technology continues to dominate terrestrial applications, occupying up to $~ 85 \%$ of the global PV market share. However, solar cells fabricated on standard boron doped CZ silicon substrates have shown a reduced cell performance after being exposed to light and even after storage in the dark [3]- [4]. Such light induced degradation (LID) effects were reported mainly from the dopant boron, which reacts with oxygen atoms under illumination [5] - [6]. The high oxygen density is a result from the standard CZ Si growth method. Hence, eliminating boron and/or oxygen from the bulk silicon is an effective way to avoid such LID effect.

In recent years, n-type Si solar cells have garnered particular interest because they hold significant advantages over p-type Si solar cells. N-type Si solar cells are not only free of the LID effect, but also have a high efficiency potential and a lower sensitivity of the carrier lifetime towards impurities. High efficiency n-type Si solar cells developed in a laboratory environment with different cell structures have been reported, such as the $24.2 \%$ efficient interdigitated back contact (IBC) cell [7], the $23.7 \%$ efficient heterojunction solar cell with intrinsic thin layer (HIT) [8], the 23.2\% efficient PERL solar cell [9], and the $22.7 \%$ efficient PERT solar cell [10].

The goal of the PV industry is to significantly lower the costs per watt in mass production in order to achieve grid parity. Although a lot of effort has been undertaken to develop different n-type Si solar cells in a laboratory environment, efficiency improvements are often reached only with the help of cost-intensive process steps so that most processing steps cannot be directly implemented into mass production. The laboratory processing technologies have to be re-engineered for low-processing cost, such as developing industrially 


\section{IEEE $38^{\text {th }}$ Photovoltaic Specialists Conference, 3-8 June 2012, Austin, USA}

applicable cost-effective processing steps compatible with the existing affordable p-type Si solar cell technology.

A novel high efficiency solar cell and module technology, named PANDA, using crystalline n-type CZ Si wafers has moved into large-scale production at Yingli. PANDA technology is the first new n-type silicon cell technology in volume production based on processes compatible with standard screen-printed cell and module manufacturing with high efficiency and low cost.

In this paper, a short review of different n-type Si solar cells that have been realized in mass production will be given. Industrial implementation and the development status of PANDA technology for highly efficiency n-type Si solar cells and modules in high volume at Yingli is presented.

\section{REVIEW OF COMMERCIAL N-Si SOLAR CELL TECHNOLOGY}

There are two successful industrial n-type Si solar cell technologies available in the market during the last years. One is the IBC structure n-type Si solar cell, and another is the HIT structure n-type Si solar cell. The conversion efficiencies of these products are 3 4\% higher than that of typical crystalline solar cells, but the costs are typically more than $40 \%$ higher [11].

\section{A. IBC n-Si solar cells}

SunPower Corporation commercialized high-efficiency IBC n-type Si solar cells originally developed by a research group of Stanford University. Figure 1 shows a schematic sketch of SunPower's IBC solar cell. Compared with traditional solar cells with metal collectors on the front surface which lower their efficiency by blocking sunlight, the IBC solar cells use metallic conductors on the back of the cell to collect the electricity generated by sunlight, which strikes the fully exposed front side of the cell. The IBC design comprises a back p-n junction cell in which both $\mathrm{p}$ and $\mathrm{n}$ contacts are in the form of interdigitated grids on the rear surface, so that the IBC cell must be fabricated on Si wafers with a long minority carrier diffusion length. The distance from any point in the cell to the junction must be much less than the diffusion length. Excellent front surface passivation is required as well.

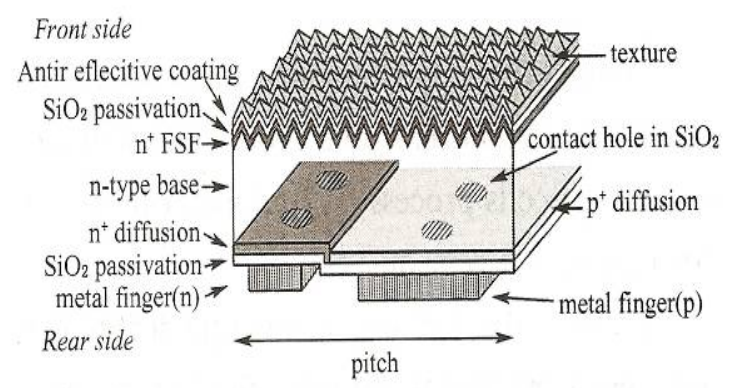

(a)
Fig.1. Schematic sketch of SunPower's IBC solar cell [12]

The first manufacture of large-area $\left(149 \mathrm{~cm}^{2}\right)$ A-300 IBC solar cells was reported in 2004 [12]. A maximum cell efficiency of $21.5 \%$ was achieved.

A high volume production of a new generation IBC solar cells with a record average efficiency of $22.4 \%$ was reported in 2007 [13]. SunPower launched commercial E20 series solar modules achieving record module efficiency of up to $20 \%$ in 2011. In a recent paper, a new record efficiency of $24.2 \%$ with a large area $\left(155.1 \mathrm{~cm}^{2}\right)$ IBC solar cell developed by the R\&D department of SunPower was reported [7].

\section{B.HIT n-Si substrate solar cells}

Another n-type Si solar cell, the so-called HIT cell, was proposed and developed by Sanyo Electric Corporation. Mass production of the HIT solar cell launched in 1997. Figure 2 shows the structure of the HIT solar cell [14]. For the HIT cells both emitter and back-surface-field (BSF) are formed by the deposition of thin doped amorphous silicon layers on an ntype Si wafer. The surface passivation is accomplished by a thin layer of intrinsic amorphous silicon. Transparent conductive oxide (TCO) layers are deposited on both doped layers followed by a silver grid for current collection. Therefore, the HIT solar cell has a symmetrical structure and can realize bifacial solar cells, which utilize the sunlight more efficiently due to converting light incident on both sides of the solar cell.

Sanyo reported R\&D HIT cell efficiency of $23.0 \%$ with a thick wafer of $>200 \mu \mathrm{m}$ (cell size $100.3 \mathrm{~cm}^{2}$ ) and $22.8 \%$ with a thin wafer of $98 \mu \mathrm{m}$ (cell size $100.4 \mathrm{~cm}^{2}$ ) in 2009 [15]. Currently, research teams of Sanyo have achieved a new laboratory record in HIT cell efficiency conversion efficiency of $23.7 \%$ on a large area $\left(100.7 \mathrm{~cm}^{2}\right)$ with a thin wafer of 98 $\mu \mathrm{m}$. Sanyo commercializes the module with $19 \%$ efficiency using HIT 21.6\% efficiency cells in volume production [16].

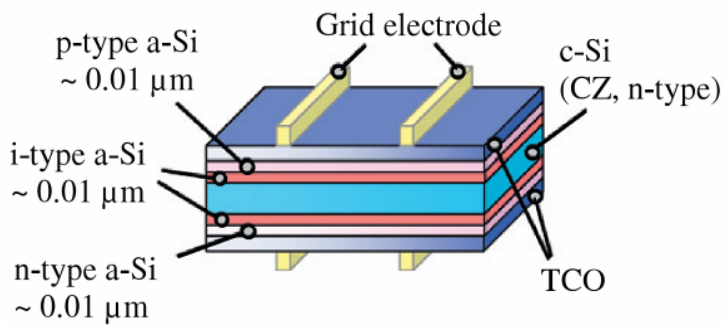

Fig. 2. Schematic sketch of Sanyo's HIT solar cell [14]

\section{PANDA TECHNOLOGY}

\section{A. PANDA solar cell}

The rapid fall in PV module prices makes the low-cost fabrication of new n-type Si solar cells a top priority. ECN [17] has developed a high efficiency n-type Si cell with low cost features including a front boron emitter, a rear 
IEEE $38^{\text {th }}$ Photovoltaic Specialists Conference, 3-8 June 2012, Austin, USA

phosphorous back-surface-field (BSF), as well as front and rear screen-printed metallization grid electrodes. The solar cell is fabricated using only industrial compatible p-type Si solar cell techniques. In June 2009, Yingli Green Energy launched a collaboration with ECN, and Amtech Systems, in a project named PANDA to develop the ECN's laboratory-scale n-type Si solar cell concept for deployment in high-volume manufacturing at Yingli without adding significant cost to the process.

A vertically integrated production model from n-type $\mathrm{Cz}-\mathrm{Si}$ crystal growth, wafer slicing, cell processing and module assembly was used in the development of PANDA technology to achieve the lowest manufacturing cost in Yingli, as shown in Figure 3. Figure 4 shows the schematic sketch of the PANDA solar cell. The process flow is shown in Figure 5 [18]. First, saw-damage is removed and surface texturing is achieved with a conventional alkaline-based wet chemistry. A co-diffusion process forms the boron emitter and the phosphorous BSF. The boron emitter was passivated with silicon nitride. Finally, screen-printed metal grid electrodes are fabricated on both sides of the cells.

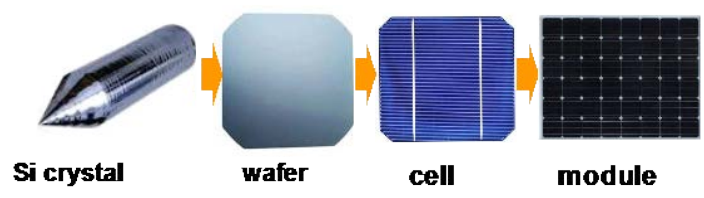

Fig.3. A vertical integrated production chain for PANDA technology

As seen in the Figure 4, an open rear contact design and transparent phosphorous BSF result in a bifacial cell structure. This means that light injection is possible from both the front and rear side of the cell, so that scattered and reflected light can enter the solar cell from the rear, enhancing the power generating capacity of the cell in case of a bifacial module layout.

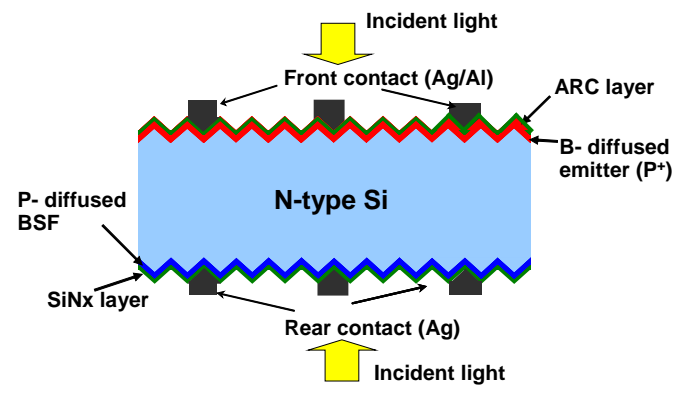

Fig.4. Schematic sketch of Yingli’s PANDA solar cell

When comparing to established n-type Si solar cell technologies, PANDA technology has several advantages, as follows: i) simplifying cell structure and easy manufacturing in volume production; ii) improving cost performance due to simple processing steps and compatible with existing p-type Si cell production lines, iii) featuring a bifacial structure to generate additional electricity, and iv) suitable for thin wafers due to a symmetrical structure.

During the past two years, Yingli has focused on achieving the lowest manufacturing cost for high efficiency PANDA technology through i) a vertically integrated production, including n-type Cz-Si crystal growth, wafer slicing, cell processing and module assembly; ii) improving in-house ntype Si growth quality, optimizing cell process parameters, yield, reducing wafer breakage, and improving continuously cell efficiency. Based on these continuous improvement efforts, Yingli PANDA solar cells on semi-square 6-inch ntype $\mathrm{CZ}$ wafers have improved to an average efficiency on commercial production lines exceeding $19.0 \%$ and up to $20.0 \%$ in pilot production (according to in-house tests, measured under STC $1000 \mathrm{~W} / \mathrm{m}^{2}$, AM1.5 global spectrum at $25^{\circ} \mathrm{C}$ ). Information on a detailed improvement of the cell effifiency sees. Ref. 19.

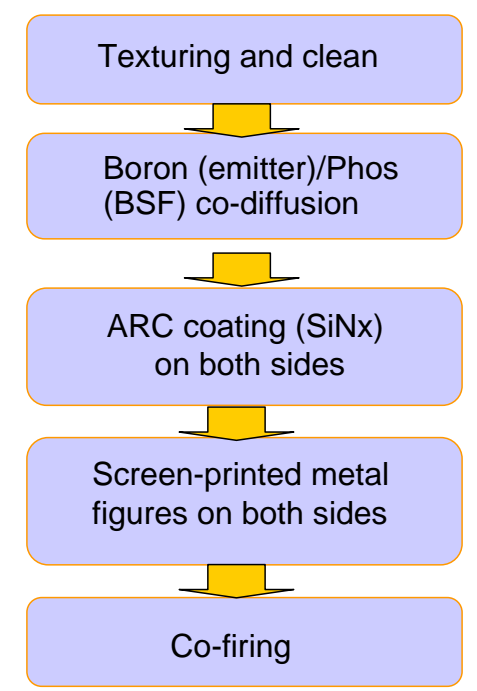

Fig.5. Flowchart of the PANDA solar cell manufacturing

\section{B. PANDA Module}

PANDA series PV modules became commercially available from the middle of 2010 and were certified according to UL1703, IEC 61215 and IEC 61730 standards. A photo of a typical PANDA PV module, as well as typical electrical performance characteristics, are shown in Figure 6. The bifacial PANDA PV module also was developed by using the bifacial structure feature of the PANDA solar cell. It has glass on both sides or uses transparent back sheet, which allows collecting light energy from both sides of the solar module. The bifacial PANDA module is most effective if mounted on a roof with a white color to reflect light to the back of the module. In this case, the bifacial PANDA module 
IEEE $38^{\text {th }}$ Photovoltaic Specialists Conference, 3-8 June 2012, Austin, USA

produces $\sim 15 \%$ more power than the single-sided PANDA module.

\begin{tabular}{|c|c|c|}
\hline 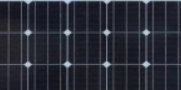 & \multicolumn{2}{|c|}{$\begin{array}{l}\text { A typical module parameters } \\
\text { of Panda } 325\end{array}$} \\
\hline & $\mathrm{V}_{\mathrm{oc}}(\mathrm{V})$ & 46.08 \\
\hline PANDA 325 & $I_{s c}(A)$ & 9.2 \\
\hline$\uparrow$ & FF (\%) & 76.5 \\
\hline 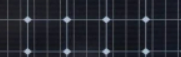 & $P_{\text {mpp }}(W)$ & 325 \\
\hline . +. & Cell eff. (\%) & 19.26 \\
\hline
\end{tabular}

Fig.6. Photo of PANDA module and typical parameters

Figure 7 shows a comparison of the initial light induced degradation (LID) between Yingli Solar PANDA n-type Si and conventional p-type Si modules. Due to the lack of boronoxygen pairs as recombination centre in the n-type cell bulk [5], PANDA modules have near zero initial LID.

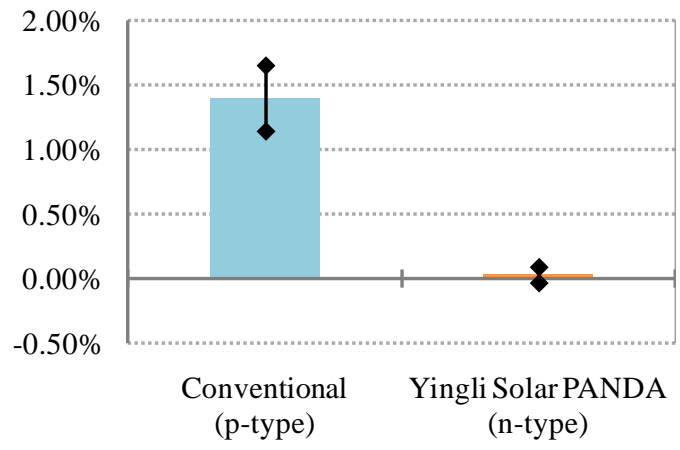

Fig.7: Comparison of initial light induced degradation (LID) between Yingli Solar PANDA n-type Si and conventional ptype Si modules.

TABLE I

COMPARISON OF TEMPERATURE COEFFICIENTS BETWEEN YINGLI SOLAR PANDA N-TYPE SI AND CONVENTIONAL P-TYPE SI MODULES

\begin{tabular}{|l|c|c|c|}
\hline $\begin{array}{l}\text { Temperature } \\
\text { coefficient for }\end{array}$ & Units & $\begin{array}{c}\text { Conventional } \\
\text { (p-type) }\end{array}$ & $\begin{array}{c}\text { Yingli Solar } \\
\text { PANDA } \\
\text { (n-type) }\end{array}$ \\
\hline $\begin{array}{l}\text { Maximum Power } \\
\left(\mathrm{P}_{\max }\right)\end{array}$ & $\% / \mathrm{K}$ & -0.45 & -0.42 \\
\hline $\begin{array}{l}\text { Open-Circuit Voltage } \\
\left(\mathrm{V}_{\text {oc }}\right)\end{array}$ & $\% / \mathrm{K}$ & -0.33 & -0.31 \\
\hline $\begin{array}{l}\text { Voltage at } \mathrm{P}_{\max } \\
\left(\mathrm{V}_{\mathrm{mpp}}\right)\end{array}$ & $\% / \mathrm{K}$ & -0.45 & -0.41 \\
\hline
\end{tabular}

Table I compares the temperature coefficients between Yingli Solar PANDA n-type Si and conventional p-type Si modules. Clearly, the PANDA modules have superior high temperature performance with temperature coefficients that are $6 \%-9 \%$ lower in magnitude than those for conventional p-type Si modules.

The yearly energy output of PV systems strongly depends on the irradiation conditions over the course of an entire year. Typically, for the larger part of the year irradiance levels are below the value of $1000 \mathrm{~W} / \mathrm{m}^{2}$ as used for laboratory characterization of modules at standard test conditions (STC). Therefore, module performance under low irradiance conditions is a crucial aspect for annual energy production.

Figure 8 shows a comparison of the relative module efficiency as a function of irradiance between Yingli Solar PANDA n-type Si and conventional p-type Si modules. From this graph, it can be seen that the PANDA modules have an excellent efficiency even at low irradiance. This is due to the fact that the minority carrier lifetime in n-type $\mathrm{Si}$ is hardly affected at low light injection levels. However, it decreases drastically for p-type $\mathrm{Si}$, because the capture cross section for holes is generally much smaller than the capture cross section for electrons, which is inversely proportional to the ShockleyRead-Hall (SRH) recombination rate [20].

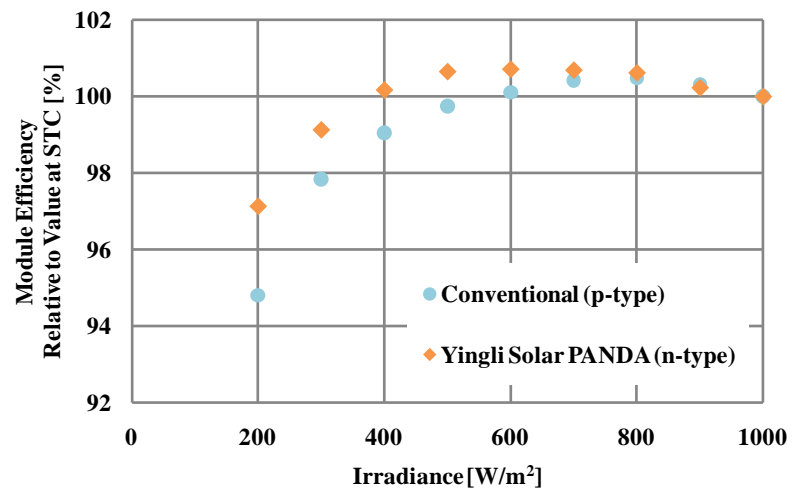

Fig. 8: Comparison of relative module efficiency as a function of irradiance for Yingli Solar PANDA n-type $\mathrm{Si}$ and conventional p-type Si modules.

\section{CONCLUSIONS}

PANDA technology is the first new n-type silicon cell technology in volume production based on processes that are compatible with standard cell and module manufacturing. With a vertically integrated business model from n-type Cz-Si crystal growth, through wafer slicing, cell processing and module assembly, Yingli has achieved the lowest manufacturing cost for high efficiency PANDA solar cell and modules. Yingli PANDA solar cells on semi-square 6-inch ntype CZ wafers have been improved to an average efficiency on commercial production lines exceeding $19.0 \%$ and up to $20.0 \%$ in pilot production. The PANDA module testing shows that the PANDA module has high efficiency and power density, superior high temperature performance, near zero initial light induced degradation, and excellent efficiency at low irradiance. 
IEEE $38^{\text {th }}$ Photovoltaic Specialists Conference, 3-8 June 2012, Austin, USA

Our target in the near future is further improving the PANDA average solar cell efficiency in mass production over $20 \%$ by studying passivation and metallization technologies for improving $\mathrm{V}_{\mathrm{oc}}, \mathrm{I}_{\mathrm{sc}}$, and FF.

\section{ACKNOWLEDGEMENTS}

The authors thank all the PANDA team members from Yingli's research centers, ECN and Amtech for fruitful collaboration in this project and further R\&D work. DS would like to thank all involved co-authors for their help with the analyses of the experimental data, the interpretation of the testing results, and the preparation of the manuscript.

\section{REFERENCES}

[1] “2011 U.S. Solar Market Report”, http://cleantechnica.com/2012/03/15/us-solar-facts-charts.

[2] "Polysilicon Prices in 2012: The tipping point for solar", http://www.investmentu.com/2012/January/polysilicon-greenenergy.html.

[3] J. Knobloch, S.W. Glunz, D. Biro, W. Warta, E. Schaffer , W. Wettling, "Solar cells with efficiencies above 21\% processed from Czochralski grown silicon", in 25th IEEE Photovoltaic Specialist Conference, 1996, pp. 405-408.

[4] J. Zhao, A. Wang and M.A. Green, "Performance degradation in CZ(B) cells and improved stability high efficiency PERT and PERL silicon cells on a variety of SEH MCZ(B), FZ(B) and CZ(Ga) Substrates", Progress in Photovoltaics, vol. 8, pp. 549-558, 2000.

[5] J. Schmidt, A.G. Aberle and R. Hezel, "Investigation of carrier lifetime instabilities in CZ-grown silicon", in 26th IEEE Photovoltaic Specialist Conference, 1997, pp. 13-18.

[6] J. Schmidt, R. Hezel, "light-induced degradation in CZ silicon solar cells: fundamental understanding and strategies for its avoidance”, in 12th Workshop on Crystalline Silicon Solar Cell Materials and Processes, 2002.

[7] P. J Cousins, D. D Smith, H. C Luan, J. Manning, T.D Dennis, A. Waldhauer, K. E Wilson, G. Harley, G. P Mulligan, "Gen III: improved performance at lower cost", in 35th IEEE Photovoltaic Specialist Conference, 2010, pp. 823-826.

[8] T. Kinoshita, D. Fujishima, A. Yano, A. Ogane, S.Tohoda, K. Matsuyama, Y. Nakamura, N. Tokuoka, H. Kanno, H. Sakata, M. Taguchi, E. Maruyama. "The approaches for high efficiency HIT solar cell with very thin $(<100 \mu \mathrm{m})$ silicon wafer over $23 \%$ ”, in 26th European Photovoltaic Solar Energy Conference, 2011, pp. 871-874.

[9] J. Benick, B. Hoex, M. C. M. van de Sanden, W. M. M. Kessels, O. Schultz, S. W. Glunz, "High efficiency n-type Si solar cells on $\mathrm{Al}_{2} \mathrm{O}_{3}$-passivated boron emitters", Appl. Phys. Lett., vol 92, 253504, 2008.

[10] J. Zhao and A. Wang, in 4th World Conference on Photovoltaic Energy Conversion, 2006, pp.996-998.

[11] "Next-Generation High Efficiency Crystalline Si Solar Cell Technology and Market Forecast (2008-2015)", Research and Markets, Nov 2011.

[12] W. P. Mulligan, D.H. Rose, M.J. Cudzinovic, D.M. De Ceuster, K.R. McIntosh, D. D. Smith, and R.M. Swanson, "Manufacture of solar cells with $21 \%$ efficiency", in 19th European Photovoltaic Solar Energy Conference, 2004, pp. 387-90.

[13] D. De Ceuster, P. Cousins, D. Rose, D. Vicente, P. Tipones, and W. Mulligan, "Low Cost, high volume production of $>22 \%$ efficiency silicon solar cells", in 22nd European Photovoltaic Solar Energy Conference, 2007, pp. 816-819.

[14] T. Mishima, M. Taguchi, H. Sakata, E. Maruyama, "Development status of high-efficiency HIT solar cells", Solar Energy Materials \& Solar Cells, vol 95, pp.18-21, 2011.

[15] H. Sakata, Y. Tsunomura, H. Inoue, S. Taira, T. Baba, H. Kanno, T. Kinoshita, M. Taguchi, and E. Maruyama, "Highefficiency HIT solar cell on thin $(<100 \mu \mathrm{m})$ silicon wafer", in 24th European Photovoltaic Solar Energy Conference, 2009. pp. 1690-1693.

[16] http://eu-solar.panasonic.net/en/products/n-240-n-235.

[17] A. Weeber, R. Naber, N. Guillevin, P. Barton, A. Carr, D. Saynova, T. Burgers, B. Geerligs, "Status of n-type solar cells for low-cost industrial production”, in 24th European Photovoltaic Solar Energy Conference, 2009, pp. 891-895.

[18] A.R. Burgers, L.J. Geerligs, A.J. Carr, A. Gutjahr, D.S. Saynova, X. Jingfeng, L. Gaofei, X. Zhuo, W. Hongfang, A. Haijiao, H. Zhiyan, P.R. Venema, A.H.G. Vlooswijk, "19.5\% efficient n-type Si solar cells made in production", in 26th European Photovoltaic Solar Energy Conference, 2011, pp. 1144-1147.

[19] L.J. Geerligs, Ingrid G. Romijn, A.R. Burgers, N. Guillevin, Arthur W. Weeber, Jan H. Bultman, H. Wang, F. Lang, W. Zhao, G. Li, Z. Hu, J. Xiong, "Progress in low-cost n-type silicon solar cell technology", in this conference.

[20] C. Gong, N. Posthuma, F. Dross, F. Giovanni, E. Van Kerschaver, G. Beaucarne, J. Poortmans, "Comparison of n- and p-type high efficiency silicon solar cell performance under low illumination conditions", in 23rd European hotovoltaic Solar Energy Conference, 2008, pp. 1360-1368. 